\title{
Correction to: Incidence and characteristics of methicillin-resistant coagulase-negative Staphylococcus in peritoneal dialysis-associated peritonitis in a single center using molecular methods
}

\author{
Carlos Henrique Camargo 1,2,3 - Maria de Lourdes Ribeiro de Souza da Cunha ${ }^{2}$. \\ Jacqueline Costa Teixeira Caramori ${ }^{1}$. Alessandro Lia Mondelli ${ }^{1}$. Augusto Cezar Montelli ${ }^{1,2} \cdot$ Pasqual Barretti $^{1}$
}

Published online: 25 September 2020

(c) Springer Nature B.V. 2020

\section{Correction to: International Urology and Nephrology https://doi.org/10.1007/s11255-020-02605-9}

In the original publication, article title was incorrectly published as "Incidence and characteristics of methicillin-resistant coagulase-negative Staphylococcus aureus in peritoneal dialysis-associated peritonitis in a single center using molecular methods".

The correct title should read as "Incidence and characteristics of methicillin-resistant coagulase-negative Staphylococcus in peritoneal dialysis-associated peritonitis in a single center using molecular methods".

The original article can be found online at https://doi.org/10.1007/ s11255-020-02605-9.

Carlos Henrique Camargo

carlos.camargo@ial.sp.gov.br

Maria de Lourdes Ribeiro de Souza da Cunha

cunhamlr@ibb.unesp.br

Jacqueline Costa Teixeira Caramori

jteixeir@fmb.unesp.br

Alessandro Lia Mondelli

dralessandro@hotmail.com

Augusto Cezar Montelli

acmontelli@uol.com.br

Pasqual Barretti

pasqual.barretti@unesp.br

1 Department of Internal Medicine, Botucatu Medical School, Sao Paulo State University, Botucatu, São Paulo, Brazil

2 Department of Microbiology and Immunology, Biosciences Institute of Botucatu, Sao Paulo State University, Botucatu, São Paulo, Brazil

3 Bacteriology Division, Instituto Adolfo Lutz, Avenida Dr. Arnaldo, 351 - $9^{\circ}$ Andar, Pacaembú, São Paulo, SP, Brasil
Publisher's Note Springer Nature remains neutral with regard to jurisdictional claims in published maps and institutional affiliations. 